の硬化度測定法の一つになりうることを明らかにした。

付記：本研究を行なうにあたり,ご指導を賜わった当研究 所長小枝幾久雄博士ならびに実験に協力された経遠敏郎, 金子 敏雄, 谷本靖男の 3 君に感謝する。なお, 示差熱分析にあたり 機器のご便宜を与えられかつ有益なご助言をいただきました東 京電機大学田島守隆氏に感謝する。本研究は, 日本化学会第 16 年会 (昭和 38 年 4 月, 東京)で発表した。

$$
\text { 文献 }
$$

1) 中島三喜男：高化，21，529(1964)
2) 伊藤勝彦：プラスチックス，5，27(1954)

3) H. P. Wohnsiedler: Ind. Eng. Chem., 45, 2307 (1953)

4) 小枝幾久雄：工化，60，1567(1957)

5）秋田 務：強化プラスチックス，4，235(1958)

6) 秋田 務: 高化, 17, 733(1960)

7) 吉見直喜, 山尾正義, 河北雅之, 田中誠之：工化, 66, 279(1963)

8) 中村儀郎：工化, 64, 150(1961)

\title{
Studies on Hardening of Amino Resins
}

\section{Comparisons of "Formaldehyde Isolation Test" with Other Methods for Determining the Degree of Cure on Melamine-Formaldehyde Resin}

\author{
By Mikio Nakajima*
}

\begin{abstract}
Comparisons of "formaldehyde isolation test" with other methods for determining the degree of cure (the transition of Rockwell hardness with temperature, differential thermal analysis, the estimation of condensation water in hardened resin, etc.) were studied.

As the results, it has been found that the values obtained by "formaldehyde isolation test" are proportinal to the amount of remaining methylol groups in hardened resin, and indicate the good correlation to the values obtained by the other methods.

Therefore, "formaldehyde isolation test" is useful for determining the degree of cure of hardened resins (in C-Stage).
\end{abstract}

第 3 報 メラミン樹脂の硬化度と硬化条件の関係および

C-Stage における硬化の動力学

(1964 年 1 月 30 日受理)

中島三喜男**

要 旨 C-Stage におけるメラミン㯕脂の硬化度 (“ホルムアルデヒド溶出試験法”による值)と硬化 条件の関倸を，皘層板を試料として研究した。さらに硬化の速度式を求め，見かけの硬化の活性化エネルギー

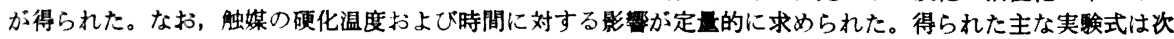
のとおりである。

$$
\begin{aligned}
C=\text { const. のとき, } & F(t T a) k_{1}=k_{2} \\
t_{c}=\text { const. のとき, } & F\left(T_{c} \cdot C a^{\prime}\right) k^{\prime}=k_{2}{ }^{\prime} \\
T_{c}=\text { const. のとき, } & F\left(C \cdot t_{c} a^{\prime \prime}\right) k^{\prime \prime}=k_{2}{ }^{\prime \prime} \\
& F\left\{t_{c}\left(T_{c} \cdot C a\right)^{\beta}\right\} r=\delta \\
-\left(\frac{\partial F}{\partial t}\right)_{T}=K F^{n}, & K=k_{1} \cdot k_{2}{ }^{-\frac{1}{k_{1}}} \cdot T a, \quad n=\frac{k_{1}+1}{k_{1}}
\end{aligned}
$$

(ただし，F：硬化度， $T$ : 硬化温度， $t$ : 硬化時間， $C$ : 触媒添加 $a, a^{\prime}, a^{\prime \prime}, k_{1}, k_{1}{ }^{\prime}, k_{1}{ }^{\prime \prime}, k_{2}, k_{2}{ }^{\prime}, k_{2}{ }^{\prime \prime}$. $\alpha, \beta, \gamma, \partial=$ const.)

* Nippon Carbide Industries Co., Inc., Tokyo Research Laboratory (615 Kamiikegami-machi, Ōta-ku, Tokyo)

** 日本カーパイド工莱㧣式会社東京研究所 (東京都大田区上池上町 615) 


\section{1. 緒言}

メラミン樹脂 (一般にはアミノ樹脂) の硬化反応 (縮合 反応) の動力学的研究は, 従来溶液反応について行なわ

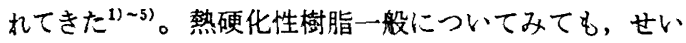
ぜいB-Stage までの硬化についての研究6) が行なわれ ているにすぎず, C-Stage の硬化に関しては報告も少な w。

これは, C-Stage においては, 樹脂の適当な分析法が なく，その硬化度を定量化することの困難性に原因があ ったから上考えられる。

著者は, さきにメラミン樹脂について, C-Stage の硬 化度測定法として, “ホルムアルデヒド溶出試験法”7),8 を提唱した。

本報では，この方法テ硬化度を測定することにより， 樹脂の硬化条件と硬化度の関俰を定量的に研究し, さら に C-Stageにおける硬化を動力学的に取り扱った結果 について述べる。

\section{2. 実験およひ結果}

\section{1 樹脂の硬化度と硬化時間および硬化温度の関係}

\section{1 .1 試 料}

a) 基材 第 1 報》に同じ。
b) 樹脂 第 1 報に同じ。
c) レジンシートの製造 第 1 報に同じ。ただし樹脂 液の $\mathrm{pH}$ は $8.8(\mathrm{~TB})$ で, 得られたレジンシートの樹 脂付着量は $64.9 \%$, 揮発分 $\left(150^{\circ} \mathrm{C}, 10 \mathrm{~min}\right.$ の乾燥减 量)は $5.10 \%$ であった。

d) 積層板の成形 上記レジンシートを 21 枚積層(直 交) し, 硬化温度 $140 \sim 160^{\circ} \mathrm{C}$, 硬化時間 $10 \sim 60 \mathrm{~min}$, 成形圧 $55 \mathrm{~kg} / \mathrm{cm}^{2}$ の条件で成形した。解板は所定時間 後直ちに行なった。板の厚さは約 $1.5 \mathrm{~mm}$ である。

\subsection{2 試料の硬化度の測定}

硬化度の測定は, “ホルムアルデヒド溶出試験法”に よった(詳細は第 1 報参照)。

ホルムアルテヒドの溶出条件は，次のとおりである。

試験片の大きさ, $30 \times 50 \mathrm{~mm}$

$0.95 \%$ 硫酸, $50 \mathrm{ml}$ 使用。

溶出温度および時間, $100^{\circ} \mathrm{C}, 10 \mathrm{~min}$

溶出ホルムアルデヒドをヨード法で定量。

\section{1 .3 実験結果およひ考察}

硬化時間 $(t \mathrm{~min})$ と, ホルムアルデヒド溶出量 $(F \mathrm{mg} /$ $\left.100 \mathrm{~cm}^{2}\right)$ の関倸を, 硬化温度 $\left(T{ }^{\circ} \mathrm{K}\right)$ をパラメーターに して Fig. 1 に示した。

この図から，樹脂の硬化は，硬化温度が高いほどまた， 硬化時間が長いほど進んでいることがわかる。

次にこの図から，Fをパラメーターにして，硬化時間

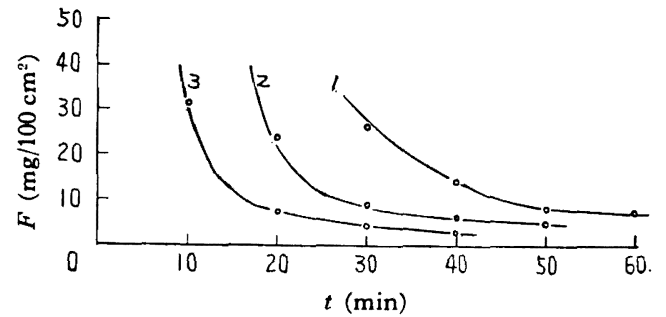

$0.95 \% \mathrm{H}_{2} \mathrm{SO}_{4}, 100^{\circ} \mathrm{C}, 10 \mathrm{~min}$

Curing temp. ( $\left.{ }^{\circ} \mathrm{K}\right) \quad 1: 413,2: 423,3: 433$ Pressure $55 \mathrm{~kg} / \mathrm{cm}^{2}$

Fig. 1. $F$ vs. curing time.

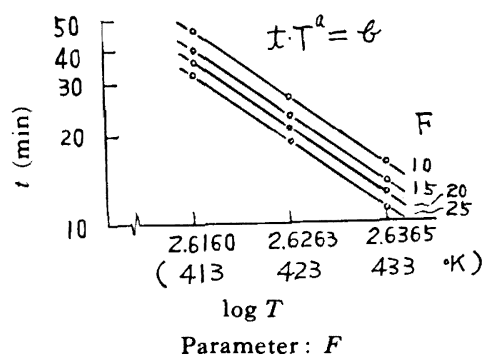

Fig. 2. $\log t$ vs. $\log T$.

と硬化温度の関係を求めると Fig. 2 が得られる。した がって, 両者の間には， $F=$ const. なるとき, 次の実験 式が成立する*1。

$$
\begin{gathered}
t \cdot T a=b \\
\text { (ここに } a, b=\text { const.) }
\end{gathered}
$$

ここで，(t.Ta) なる量は，硬化度を表わす量であるこ とがわかる。そこで $(t \cdot T a)$ とその $t, T$ における $F$ の 值を両対数グラフにプロットすると, Fig. 3 が得られ た。

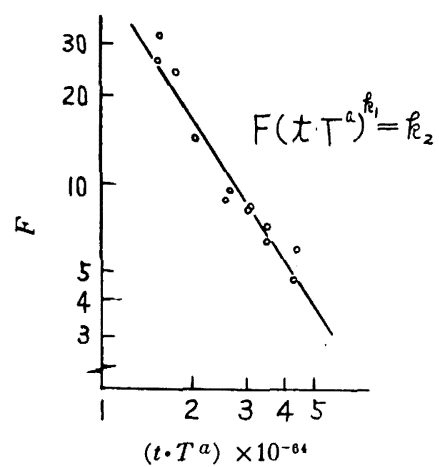

Fig. 3. $\log F$ vs. $\log (t \cdot T a)$.

*1 ただし，たとえばフェノール楜脂などの硬化反応で，反応 至が応時間と直線関係を示す籍囲内では，反応温度 $(T)$ と反 応時間 $(t)$ の間に, $\log t \propto 1 / T$ の関保が飒められている10),11。 
この図から，次式が得られる。

$$
\begin{gathered}
\log F=-k_{1} \log \left(t \cdot T^{a}\right)+\log k_{2} \\
\therefore \quad F\left(t \cdot T^{a}\right) k_{1}=k_{2}
\end{gathered}
$$

(ただし $k_{1}, k_{2}=$ const.)

すなわち，樹脂の硬化度をホルムアルデヒド溶出量 $(F)$ で表わすとき，その值と硬化時間および硬化温度の 間には (3) 式の関係があることを知った。

2.1.4 硬化の速度式および硬化の見かけの活性化工 ネルギー

硬化の速度式は (3) 式から誘導される。すなわち，

$$
\begin{aligned}
& F=k_{2} \cdot T^{-a k_{1} \cdot t^{-k_{s}}} \\
& -\left(\frac{\partial F}{\partial t}\right)_{T}=K \cdot F^{n}
\end{aligned}
$$

ただし，

$$
\begin{aligned}
& K=k_{1} \cdot k_{2}^{-\frac{1}{k_{1}}} \cdot T^{a} \\
& n=\frac{k_{1}+1}{k_{1}}
\end{aligned}
$$

(4) 式左辺は, 硬化温度一定なるときの $F$ の堿少速 度であって，F は未硬化の残存メチロール基量にパラレ ルな值である ${ }^{8)}$ から, 結局 (4) 式は硬化の速度式という ことができる。 $K$ は硬化速度定数に相当する値である。

次に, Fig. 2, 3 から $a, k_{1}$ の值を, さらに計算から $k_{2}$ の值を求め, $T$ が $413,423,433^{\circ} \mathrm{K}$ のときの $K$ を (5) 式から計算すると, Table 1 に示すよ5な值が得ら れる。

Table 1. Values of constant on equation (3) and (5).

\begin{tabular}{c|c|c|c|r}
$T\left({ }^{\circ} \mathrm{K}\right)$ & $a$ & $k_{1}$ & $k_{2}$ & $K \times 10^{8}$ \\
\hline 413 & 23.97 & 1.578 & $6.786 \times 10^{102}$ & 6.62 \\
423 & $"$ & $"$ & $"$ & 11.69 \\
433 & $"$ & $"$ & $"$ & 20.53 \\
\hline
\end{tabular}

$\log K$ と $1 / T$ の Arrhenius plot (Fig. 4) から, 硬化 の見かけの活性化エネルギー求めると, $20.5 \mathrm{kcal} / \mathrm{mol}$ の值が得られた。これは溶液状態における初期縮合反応 (メチレン化反応)の活性化エネルギー $21 \mathrm{kcal} / \mathrm{mol}$ とほ ぼ同程度の值である゙》。

\section{2 捯脂の硬化度と硬化温度および触媒添加量の関 係(硬化時間一定なる場合)}

\subsection{1 試 料}

基材および樹脂は, 2.1 節と同しものを使用した。触

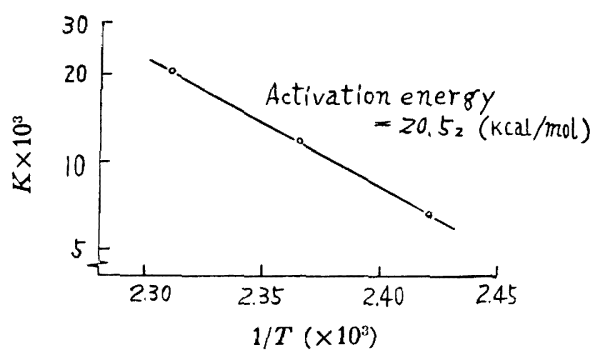

Fig. 4. Apparent rate constant of curing vs. $1 / T$.

媒 (キアタニット A-日東化学工業製) は, 基材含浸の際 樹脂液に添加して用いた。

含浸は手で行ない, 乾燥は $70^{\circ} \mathrm{C}$ で $10 \sim 15 \mathrm{~min}$ 行な った。

得られたレジンシートの樹脂付着量は $68.2 \sim 70.9 \%$, 揮発分は 7.7 11.9\% であった。

積層板の成形は，前節と同様であるが，硬化時間およ び成形圧をそれぞれ $15 \mathrm{~min}$ および $60 \mathrm{~kg} / \mathrm{cm}^{2}$ で一定 とし，硬化温度および触媒添加量の異なる試料を調整し た。

\subsection{2 試料の硬化度の測定}

2.1.2 における $0.95 \%$ 硫酸の代わりに, $3.03 \%$ 硫 酸を用いた以外は全く同様にして行なった。

\subsection{3 実験結果および考察}

触媒添加量(樹脂液中の樹脂固形分 100 部に対する添 加量 $\mathrm{m} l$ ) とホルムアルデヒド溶出量 (硬化度)の関倸を, 硬化温度をパラメーターにして示したものが Fig. 5 で ある。

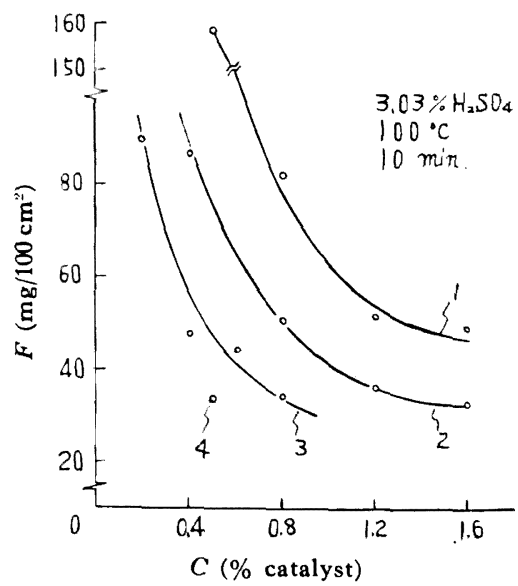

Catalyst: CATANITTO-A (NITTO Chemicals) Curing time (min): 15

Curing temp. ( $\left.{ }^{\circ} \mathrm{K}\right) 1: 393,2: 403,3: 413,4: 423$

Fig. 5. $F$ vs. $C$. 
この図から，Fをパラメーターにして硬化温度 $\left(T_{c}\right)$ と触媒添加量 $(C)$ の関係を, 両対数グラフにプロットす ると, Fig. 6 が得られる。

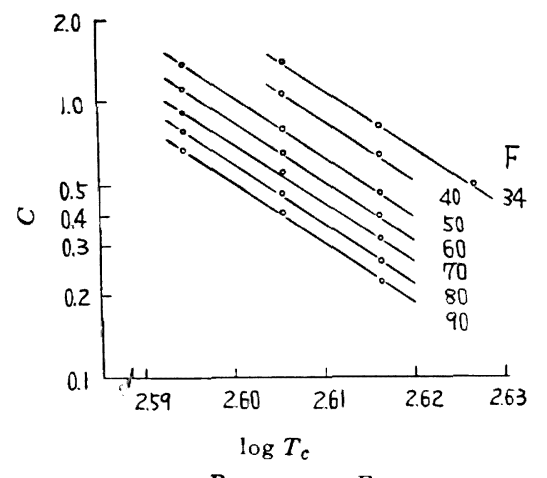

Fig. 6. $\log C$ vs. $\log T_{c}$.

Fig. 6 から，次式 (7) が成立することがわかる。

$$
C \cdot T_{c} \dot{a}=\dot{b}
$$

次に前節と同様化して， $\left(C \cdot T_{c} \dot{a}\right)$ とその $C, T_{c}$ にお ける $F$ の值を両対数グラフにプロットすれば, Fig. 7 が得られた。

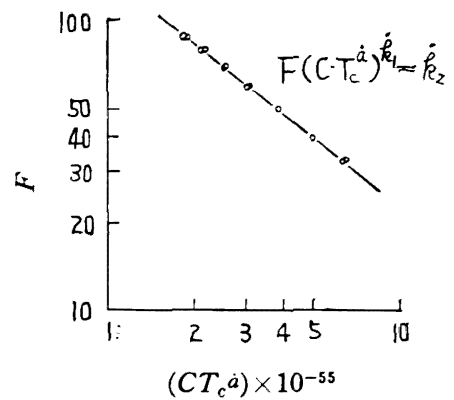

Fig. 7. $\log F$ vs. $\log \left(C \cdot T_{c} \dot{a}\right)$.

この図から次式 (8) を得る。

$$
\begin{array}{r}
F\left(C \cdot T_{\mathrm{c}} \dot{a}\right) \dot{k}_{1}=\dot{k}_{2} \\
\text { (ただし } \left.\dot{a}, \dot{k}_{1}, \dot{k}_{2}=\text { const. }\right)
\end{array}
$$

この関係から，硬化時間一定(ここでは $15 \mathrm{~min}$ ) なる とき, 任意の硬化度を有する積層板の硬化条件(触媒量 と硬化温度)を求めることができる。

Fig. 6，7 から $\dot{a}$ および $\dot{k}_{1}$ を求め，(8) 式に代入し て $\dot{k}_{2}$ を求めたときの值を Table 2 に示す。

(8) 式に拈ける $F$ の值は, $3.03 \%$ 硫酸を用いて溶出 を行なったときのものであった。そこで前節と同し
Table 2. Values of constant on equation (8) and (11).

\begin{tabular}{l|l|l|l}
\hline$\dot{a}$ & $2.137 \times 10$ & $a^{\prime}$ & $4.679 \times 10^{-2}$ \\
$\dot{k}_{1}$ & $8.226 \times 10^{-1}$ & $k_{1}{ }^{\prime}$ & $1.758 \times 10$ \\
$\dot{k}_{2}$ & $2.613 \times 10^{47}$ & $k_{2}^{\prime}$ & $1.219 \times 10^{47}$ \\
\hline$a^{\prime}=1 / a$, & $k_{1}^{\prime}=a \dot{k}_{1}, \quad k_{2}{ }^{\prime}=\dot{k}_{2} / p$, & $t_{c}=15(\mathrm{~min})$
\end{tabular}

$0.95 \%$ 硫酸を用いたときの $F$ の值に換算してみる。

今, 硬化度の異なる 3 種の試料の, 水, $0.95 \%$ 硫酸お よび $3.03 \%$ 硫酸によるホルムアルデヒド溶出量(いず れも $100^{\circ} \mathrm{C} て ゙ ~ 10 \mathrm{~min}$ 間溶出)の值を, 酸濃度 (濃度 0 を 水とする)に対してプロットすれば, Fig. 8 が得られる。

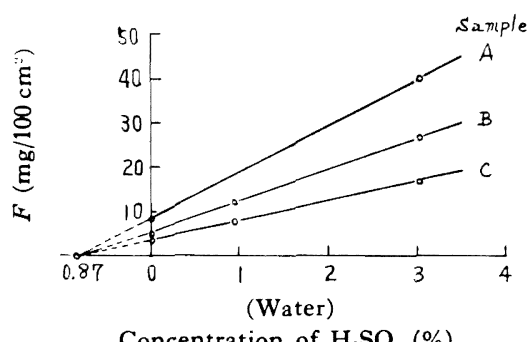

Concentration of $\mathrm{H}_{2} \mathrm{SO}$ ( (\%)

Fig. 8. $F$ vs. acid concentration of solution.

この図からわかるように，酸濃度とホルムアルデヒド

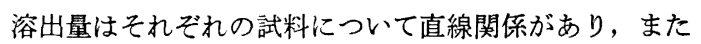
いずれの硬化度の試料も, その直線は $-0.87 * 2$ の点に 収れんするから，次の実験式が成立する。

すなわち， $3.03 \%$ 硫酸で溶出したときのホルムアル デヒド溶出量を $f, 0.95 \%$ 硫酸で溶出したときのそれ を $F$ とすれば，

$$
\begin{aligned}
\frac{f}{F}= & \frac{3.03-(-0.87)}{0.95-(-0.87)}=2.14=p \text { (const.) } \\
& \therefore \quad f=p \cdot F
\end{aligned}
$$

そこで (8) 式の $F$ の代わりに $f$ を代入すると，ホル ムアルデヒドの溶出試験を $0.95 \%$ 硫酸で行なったとき の関倸式が得られる。すなわち $\left(8^{\prime}\right)$ 式を得る。

$$
\begin{gathered}
p \cdot F\left(C \cdot T_{c} \dot{a}\right)^{\dot{k}_{1}}=\dot{k}_{2} \\
F\left(C \cdot T_{c} \dot{a}\right) \dot{k}_{1}=\frac{\dot{k}_{2}}{p}
\end{gathered}
$$

\section{3 樹脂の硬化度と触媒添加量および硬化時間の関 係 (硬化温度一定なる場合)}

前節の $\left(8^{\prime}\right)$ 式は, 次のごとく変形できる。

*2 本実験に使用した墈脂の場合の值であって，椹脂が異なれ ば，当然異なる值となる。 


$$
F\left(C^{\frac{1}{\dot{a}}} \cdot T_{c}\right) \dot{a} \dot{k}_{1}=\frac{\dot{k}_{2}}{p}
$$

ここで, $1 / \dot{a}=a^{\prime}, \dot{a} \dot{k}_{1}=k_{1}{ }^{\prime}, \dot{k}_{2} / p=k_{2}{ }^{\prime}$ とおけげ, 式を得る。

$$
F\left(T_{c} \cdot C a^{\prime}\right) k_{1}{ }^{\prime}=k_{2}{ }^{\prime}
$$

(11) 式の定数 $\left(a^{\prime}, k_{1}{ }^{\prime}, k_{2}{ }^{\prime}\right)$ の值は Table 2 に示し た。

2.1 節において, 触媒一定 (特に使用せず, 樹脂液の $\mathrm{pH}$ のままのとき) なるとき, 次の関係があることを知 った。

$$
F(t \cdot T a) k_{1}=k_{2}
$$

(3) および (11) 式から類推すれば, 硬化温度一定なる 場合は, 次式 (12) の成立が予想できる $\left(t_{c}\right.$ は触媒使用 時の硬化時間)。

$$
\begin{gathered}
F\left(C \cdot t_{c} a^{\prime \prime}\right)^{k_{1}^{\prime \prime}}=k_{2}{ }^{\prime \prime} \\
\left(\text { ただし } a^{\prime \prime}, k_{1}^{\prime \prime}, k_{2}{ }^{\prime \prime}=\text { const. }\right)
\end{gathered}
$$

\section{4 樹脂の硬化度と硬化時間, 硬化温度および触媒添 加量の関係}

上述のごとくして得た (3)，(11)，(12) 式から，ある硬 化度を示す $F$ の值は, 硬化温度 $(T)$, 硬化時間 $(t)$, 触 媒添加量 $(C)$ をそれぞれ対数目盛で示した 3 次元の図 において，Fig. 9 のごとき平面上にあることが理解で きる。

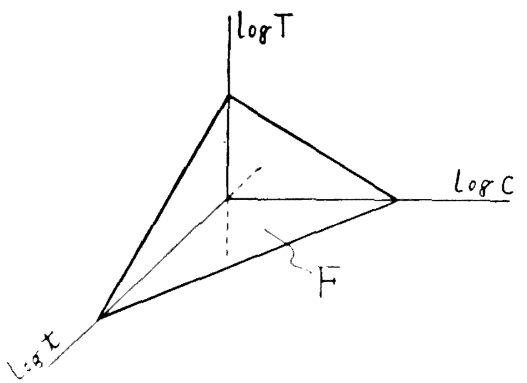

Fig. 9. Surface showing the degree of cure $(F)$.

$F$ の值が変わ札ば,この平面は $t \sim C$ 軸に垂㨁方向に 平行移動することが容易にわかる。

\section{5 硬化温度に対する触媒の効果}

触媒を使用する場合の主たる目的は, 硬化温度を低下 せしめること, あるいは硬化時間を短縮することなどに ある。

本節では, 触媒の硬化温度に対する寄与について検討 する。

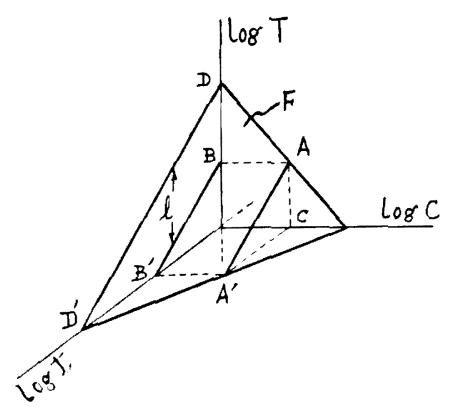

Fig. 10 .

Fig. 10 において, 今, 任意の硬化度 $F$ の面を考え る。触媒の添加がない場合， D, D' の直線は

$$
F(t \cdot T a) k_{1}=k_{2}
$$

で与えられる $(T, t$ 軸は実際には $C \fallingdotseq 0.2$ の点で交わ っている。たとえば $\left(8^{\prime}\right)$ 式 $\left(\left(t_{c}=15\right.\right.$ の場合 $\left.)\right)$ において, $F=22.2, C=0.2$ のとき $T_{c}=273+157.5$ の值が得ら れる。

(3) 式において, $F=22.2, t=15$ のとき, $T=273+$ 154.2 の值が得られる。すなわち, Fig. 11 のように, 触媒なしの場合の $t \sim T$ の関俰を示す面が $C$ 軸の 0.2 の点を切っているとすれば, $F=22.2$ の面が $t=15$ に おいて $T$ 軸を切る点は, $C \sim T_{\mathrm{c}}$ の関係式から求めたと きと, $t \sim T$ の関係式から求めたときと, ほぼ一致した 值を示すことになる。このことは, $C$ 軸の約 0.2 の点 で, $T$ 軸と $t$ 軸が交わっていることを示している)。

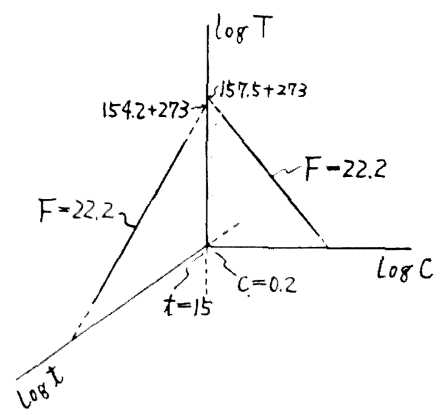

Fig. 11.

触媒添加量が $C$ なるとき, 硬化温度 $\left(T_{c}\right)$ と硬化時間 の関倸は, 直線 $\mathrm{AA}^{\prime}$ で示される。すなわち $\mathrm{AA}^{\prime}$ の $t \sim$ $T$ 面への透影 $\mathrm{BB}^{\prime}$ で示される。この直線は明らかに DD'に平行であるから，次式で表わすことができる。

$$
\begin{aligned}
F\left\{t \cdot\left(T_{c}+\Delta T\right) a\right\} k_{1}=k_{2} \\
\left(\text { ただし } \Delta T=T-T_{c}\right)
\end{aligned}
$$


$F$ の面は, $F$ の値が変わるとき $C \sim t$ 面に垂直に平行 移動するのであるから，Cが一定のときは $F$ の值に関 倸なく $\mathrm{BB}^{\prime}$ と $\mathrm{DD}^{\prime}$ の直線の距離は常に一定である。 したがって, BD の距離をlとすれば,

$$
l=\log T-\log T_{c}=\log m
$$

とおくことができる。すなわち（14）式を得る。

$$
\frac{T}{T_{c}}=m \text { ， あるいは } T_{c}=\frac{T}{m}
$$

また， $T_{\mathrm{c}}+J T=T$ であって，(14) 式から $T=m T_{\mathrm{c}}$ であるから，(13) 式は次のように改められる。

$$
F\left\{t\left(m T_{c}\right) a\right\} k_{1}=k_{2}
$$

すなわち, 触媒を $C$ だけ添加したときは, 触媒を使 用しないときの硬化温度の $1 / m$ の温度で同じ硬化度を 得ることができることが明らかになった。

次に実際に $m$ の值を計算してみよう。

$\left(8^{\prime}\right)$ 式において $(t=15$ のとき成立), Table 2 に示し た定数の値を用い， $F=22.2 ， C=0.3$ のときの $T_{c}$ を 計算すれば, $(273+150.1)$ となる。

また，(3) 式において $F=22.2, t=15$ のときの $T$ を 計算すれば, $(273+154.2)$ となる。したがって, $m=$ $(273+154.2) /(273+150.1)=1.0097$ を得る。同様にし て, 触媒量を変えた場合の $m$ の計算值を Table 3 に 示す。

Table 3. Catalyst effect on curing temperature. (When curing time is constant and the degree of cure reaches constant value)

\begin{tabular}{cc}
$C$ & $m^{*}$ \\
\hline 0 & 1 \\
0.3 & $1.009_{7}$ \\
0.5 & 1.034 \\
0.7 & $1.055_{7}$
\end{tabular}

* $m=T / T_{c}$

$T_{c}$ : Curing temperature when catalyst is added in varnish

Catalyst: CATANITTO-A (Nitto Chemicals)

2.6 澍脂の硬化度 $(\boldsymbol{F})$, 硬化温度 $\left(\boldsymbol{T}_{c}\right)$, 硬化時間 $\left(\boldsymbol{t}_{c}\right)$ およひ触媒量 $(\boldsymbol{C})$ の関係

$C=C_{0}=0$ のとき,

$$
F(t \cdot T a) k_{1}=k_{2}
$$

$t_{\mathrm{c}}=t_{0}=15$ のとき,

$$
F\left(T_{c} \cdot C a^{\prime}\right) k_{1}^{\prime}=k_{2}^{\prime}
$$

$$
C=C \text { のとき, }
$$

$$
\begin{aligned}
F\left\{t_{c}\left(m T_{c}\right) a\right\} k_{1} & =k_{2} \\
m & =\frac{T}{T_{c}}
\end{aligned}
$$

上記実験式の成立することは, すでに述べた。

(3) 式より,

$$
T=\left(k_{2} \cdot F^{-1} \cdot t_{0}-k_{1}\right)^{-\frac{1}{a k_{1}}}
$$

(11) 式より,

$$
T_{c}=\left(k_{2}{ }^{\prime} \cdot F^{-1} \cdot C^{-a^{\prime} k_{1}{ }^{\prime}}\right)^{\frac{1}{k_{1}}}
$$

(16)，(17）式を(14) 式に代入し整理すれば,

$$
m={k_{2}}^{\frac{1}{a k_{1}}} \cdot k_{2}{ }^{-\frac{1}{k_{1}^{\prime}}} \cdot F^{\frac{1}{k_{1}^{\prime}}-\frac{1}{a k_{1}}} \cdot t_{0}^{-\frac{1}{a}} \cdot C a^{\prime}
$$

\begin{tabular}{|c|c|c|c|}
\hline$\alpha$ & $4.679 \times 10^{-2}$ & $a^{\prime \prime}$ & $8.913 \times 10^{-1}$ \\
\hline 3 & $2.397 \times 10$ & $k_{1}^{\prime \prime}$ & $8.228 \times 10^{-1}$ \\
\hline$\gamma$ & $7.333 \times 10^{-1}$ & $k_{2}^{\prime \prime}$ & $9.162 \times 10$ \\
\hline$\grave{o}$ & $8.882 \times 10^{47}$ & \multicolumn{2}{|c|}{$T_{c}=413\left({ }^{\circ} \mathrm{K}\right)$} \\
\hline
\end{tabular}

(18) 式を(15') 式に代入し整理すれば,

$$
F\left\{t_{c}\left(T_{c} \cdot C a^{\prime}\right) a\right\}^{\frac{k_{1}{ }^{\prime}}{a}}=k_{2}{ }^{\prime} \cdot t_{0}{ }^{\frac{k_{1}{ }^{\prime}}{a}}
$$

すなわち， $F, t_{c}, T_{c}$ および $C$ の関倸式が得られた。 さらに (19) 式は次のごとく整理できる。

$$
\begin{gathered}
F\left\{t_{c}\left(T_{c} \cdot C^{\alpha}\right)^{\beta}\right\} r=\delta \\
\text { (ただし } \alpha, \beta, \gamma, \delta=\text { const.) }
\end{gathered}
$$

$\alpha, \beta, \gamma$ およびっの計算值を Table 4 に示す。

Table 4. Values of constant on equation

$$
\text { (20) and }\left(12^{\prime}\right) \text {. }
$$

(20) 式において, $T_{c}=T_{0}(=$ const.) とおいて整理すれ ば,

$$
F\left(C \cdot t_{c} a^{\prime \prime}\right) k_{1}^{\prime \prime}=k_{2}^{\prime \prime}
$$

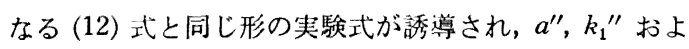
び $k_{2}{ }^{\prime \prime}$ の值は容易に計算できる。 $T_{\mathrm{c}}=413$ のときの值 を Table 4 に示す。

\section{7 硬化時間に対する触媒の効果}

触媒を使用寸机ば，同一硬化時間で同一硬化を得たい

*3 (15) 式において $t$ の代わりに $t_{c}$ 左用いた式を $\left(15^{\prime}\right)$ 式と する。 
Table 5. Comparison of $F$ obserbed with $F$ calculated from eguation (3) and (20).

\begin{tabular}{|c|c|c|c|c|c|c|c|}
\hline & & Iring conditio & & $F$ & $f$ & $F$ & $f$ \\
\hline & Temp. $\left({ }^{\circ} \mathrm{K}\right)$ & Time $(\min )$ & Catalyst $(\%)$ & \multicolumn{2}{|c|}{ (Calculated) } & \multicolumn{2}{|c|}{ (Observed) } \\
\hline \multirow{2}{*}{$\begin{array}{l}\text { Equation } \\
\text { (3) }\end{array}$} & 418 & 20 & 0 & 42.90 & 91.81 & - & 93.6 \\
\hline & 443 & 10 & 0 & 14.27 & 30.54 & - & 27.2 \\
\hline \multirow{2}{*}{$\begin{array}{l}\text { Equation } \\
\quad(20)\end{array}$} & 403 & 15 & 1.0 & 19.62 & 41.98 & - & 42.0 \\
\hline & 423 & 15 & 0.5 & 14.83 & - & 16.0 & - \\
\hline
\end{tabular}

$f$ : Formaldehyde isolated into $3.03 \% \mathrm{H}_{2} \mathrm{SO}_{\text {, }}$

$F$ : Formaldehyde isolated into $0.95 \% \mathrm{H}_{2} \mathrm{SO}$, (at $100^{\circ} \mathrm{C}$, for $10 \mathrm{~min}$ )

埸合に，硬化温度を低下することができ，あるいは同一 硬化温度で目的を達するには硬化時間を短縮することの 可能なことは良く知られている。

硬化温度に対する触媒の効果はすでに, 2.5 節で述べ たとおりで, 硬化時間一走なるとき, 同一硬化度 $(F)$ を 得るに要する触媒の添加がないときの硬化温度 $(T)$ と, 触媒添加量 $(C)$ のときの硬化温度 $\left(T_{c}\right)$ の比 $m$ は, 一 般に 2.6 節 $(18)$ 式で示される。

本節では, 硬化時間に対する触媒の効果を示す一般式 を求める。

(3) 式 $F(t \cdot T a)^{k_{1}}=k_{2}$ 加,

$$
t=k_{2} \stackrel{1}{k_{1}} \cdot F^{-\frac{1}{k_{1}}} \cdot T^{-a}
$$

また，(20) 式 $F\left\{t_{c}\left(T_{c} \cdot C a\right) j\right\} r=\delta$ から

$$
t_{c}=\delta^{\frac{1}{r}} \cdot F^{-\frac{1}{r}} \cdot T_{c}^{-\beta} \cdot C^{-\alpha \beta}
$$

今, 硬化温度一定なるとき, 同一硬化度 $(F)$ を得るに 要する硬化時間 $t$ および $t_{c}$ の比を求めるのであるから (21) 式および (22) 式に扔て $T=T_{\mathrm{c}}=T_{1}$ とおき，そ れぞれ兩辺の比を計算する。

$$
\begin{aligned}
& \left.p=\frac{t}{t_{c}}=k_{2}^{\frac{1}{k_{1}}} \cdot j-\frac{1}{\gamma} \cdot F^{\frac{1}{\gamma}-\frac{1}{k_{1}}} \cdot T_{1^{j}-\alpha} \cdot C \alpha_{1}\right\} \\
& \text { ここで, } \alpha=a^{\prime}, \beta=a, \gamma=k_{1}{ }^{\prime}\left|a, \delta=k_{2}{ }^{\prime} \cdot t_{0}{ }^{k_{1}}{ }^{\prime}\right| a \text { なるゆえ }
\end{aligned}
$$

$$
p=\frac{1}{k_{2}} \cdot k_{2}{ }^{-\frac{a}{k_{1}{ }^{\prime}}} \cdot t_{0}^{-1} \cdot F^{\stackrel{a}{k_{1}{ }^{\prime}}-\frac{1}{k_{1}}} \cdot T_{1} a-a^{\prime} \cdot C a a^{\prime}
$$

ここに得られた (23) 式は, 触媒添加量 $C$ なるとき, 硬化度 $F$ を得るには, 触媒を使用しないときの $1 / p$ の 時間で硬化可能なことを示している。

\section{3. 応用例}

一般式((20) 式)および触媒を添加しない場合の実験式 ((3) 式) から計算によって求めた樹脂の硬化度と, その
硬化条件下で成形した試料 (成形圧, $55 \sim 60 \mathrm{~kg} / \mathrm{cm}^{2}$ ) の 実測值を比較すると，Table 5 のようになる。

この表からわかるように，実験式から求めた硬化度 と，実測値は良く一致する。したがって，この実験式を 用いて任意の硬化度を得る硬化条件を推定することがで きる。

\section{4. 樹脂の硬化度と硬化温度, 硬化時間および 触媒添加量の関係を示すグラフ}

座標軸に $T, t$ および $C$ の対数を目盛れば， $F$ なる 硬化度を示す面は，Fig. 12 のごとき平面になることは 既述した。今， $F=25$ および 40 の面が各軸を切る点を (20) 式から計算して同図に示した。

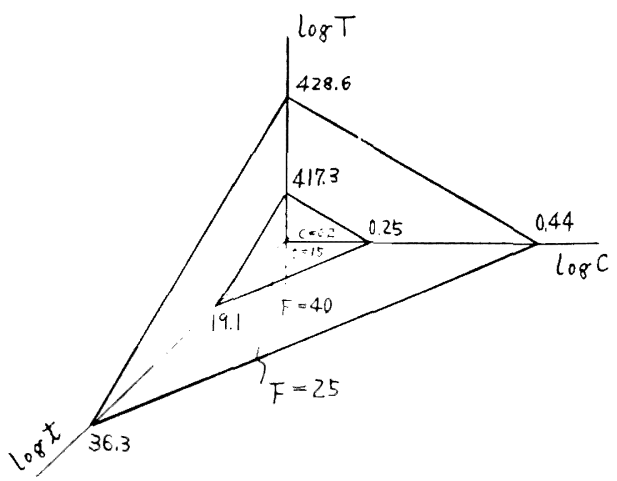

Fig. 12. Relation among curing conditions (temperature, time and catalyst added in varnish).

\section{5. 実験式のまとめ}

1) $C=$ const., $F(t \cdot T a)^{k_{1}}=k_{2}$

$C=0$ のとき, $a=2.397 \times 10, k_{1}=1.578$,

$k_{2}=6.786 \times 10^{102}$

2) $t_{c}=$ const., $F\left(T_{c} \cdot C a^{\prime}\right) k_{1}{ }^{\prime}=k_{2}{ }^{\prime}$

$t_{c}=15$ のとき, $a^{\prime}=4.679 \times 10^{-2}$,

$k_{1}{ }^{\prime}=1.758 \times 10, \quad k_{2}{ }^{\prime}=1.219 \times 10^{47}$ 
3) $T_{c}=$ const., $F\left(C \cdot t_{c} a^{\prime \prime}\right) k_{1}{ }^{\prime \prime}=k_{2}{ }^{\prime \prime}$

$T_{c}=413$ のとき, $a^{\prime \prime}=8.913 \times 10^{-1}$,

$k_{1}{ }^{\prime \prime}=8.228 \times 10^{-1}, k_{2}{ }^{\prime \prime}=9.162 \times 10$

4) 一般式, $F\left\{t_{\mathrm{c}}\left(T_{\mathrm{c}} \cdot C^{\alpha}\right) \beta\right\} r=\delta$

$\alpha=4.679 \times 10^{-2}, \quad \beta=2.397 \times 10$,

$\gamma=7.333 \times 10^{-1}, \quad \delta=8.882 \times 10^{47}$

5）硬化温度に対する触媒の効果

$$
\begin{gathered}
\frac{T}{T_{c}}=k_{2}^{\frac{1}{a k_{1}}} \cdot k_{2}{ }^{-\frac{1}{k_{1}^{\prime}}} \cdot F^{\frac{1}{k_{1}{ }^{\prime}}-\frac{1}{a k_{1}}} \cdot t_{0}^{-\frac{1}{a}} \cdot C a^{\prime} \\
\left(t_{0}=15\right)
\end{gathered}
$$

6) 硬化時間に対する触媒の効果

$$
\frac{t}{t_{c}}=k_{2}^{\frac{1}{k_{1}}} \cdot k_{2}{ }^{-\frac{a}{k_{1}^{\prime}}} \cdot t_{0}^{-1} \cdot F^{\frac{a}{k_{1}^{\prime}}-\frac{1}{k_{1}}} \cdot T a-a^{\prime} \cdot C a a^{\prime}
$$

$F:$ ホルムアルデヒド溶出量 $\left(0.95 \%\right.$ 硫酸, $100^{\circ} \mathrm{C}$, $10 \mathrm{~min}),\left(\mathrm{mg} / 100 \mathrm{~cm}^{2}\right)$

$T, T_{c}$ ：それぞれ，触媒なしのときと触媒添加のとき の硬化温度 $\left({ }^{\circ} \mathrm{K}\right)$

$t, t_{\mathrm{c}}$ ：それぞれ，触媒なしのときと触媒添加の上きの 硬化時間 $(\mathrm{min})$

$C$ ：触媒キアタニットA $\mathrm{A}$ のニス中への添加量 (樹 脂固形分 100 部门対方る $\mathrm{m} l$ )

定数の值はもちろん実験に使用した樹脂（ニカレジン S-260)の場台に適用される。

一般式の成立範囲は、大体次のように考えられる。

$$
\begin{aligned}
& T\left(T_{c}\right)=393 \sim 433 \\
& t\left(t_{c}\right)=10 \sim 60 \\
& C=0.2 \sim 1.4 \\
& \text { レシシンシートの樹脂付着量： } 65 \sim 75 \%
\end{aligned}
$$$$
\text { 樌層板の厚さ： ca. } 1.5 \mathrm{~mm}
$$

\section{6. 総 括}

(1) メラミン樹脂（ニカレジン S-260一日本カーバ イド製一)の C-Stage における硬化を“ホルムアルデ ヒド溶出試験法”を用いて検討した。

（2）触媒量一定なる場合, 硬化度, 硬化温度および 硬化時間の間の実験式を得た。この式から硬化の速度式 を誘導し, 硬化の速度定数と硬化温度の Arrhenius plot から, 硬化の活性化エネルギーとして約 $20.5 \mathrm{kcal} / \mathrm{mol}$ の値を得た。

（3）硬化時間一定なる場合, 硬化度, 硬化温度およ
び触媒添加量の間の実験式を得た。

（4）硬化温度一定なる場合, 硬化度, 硬化時間およ び触媒添加量の間の実験式を類推した。

（5）さらに，硬化度と硬化条件 ${ }^{* 4}$ (温度, 時間および 触媒量)の間の実験式を得た。この式から任意の硬化度 を与える硬化条件ないしは適正硬化度*5 を得るための硬 化条件を選定することができる。

（6）触媒は, 硬化に際して, その硬化温度あるいは 硬化時間に影響するところが大きいことはよく知られて いる。

$$
\text { その影響の程度を定量的に示す実験式を求めた。 }
$$

以上のごとく，従来取扱いの困難であった C-Stage における樹脂の硬化度を, 硬化条件との定量的関係に導 き，動力学的取扱いをも可能にすることができた。

これらの結果は, 積層板に限らず, メラミン樹脂成形 物に対しても適用できると考えられる。

尿素樹脂に対して, “ホルムアルデヒド溶出試験法” を適用するには，温和な溶出条件を選ぶことが必要と考 えられるが，その検討は今後の問題としたい。

付 記：本研究を行ならにあたり,ご指導を賜わった当研究 所長小枝幾久雄博士ならびに実験に協力された経遠敏郎, 金子 敏雄, 川田保の 3 君に感剑する。なお，本研究は，第 13 回熱硬 化性樹脂講演討論会 (昭和 38 年 10 月, 東京)で発表した。

$$
\text { 文献 }
$$

1) 小方芳郎, 岡野正弥：J. Am. Chem. Soc., 74, $5728(1952)$

2）小枝幾久雄：高化， 16，62(1959)

3）祖父江寛，村上謙吉：高化，9，454(1952)

4) Smets, Borzee: J. Polymer Sci., 8, 371(1952)

5）垣内 弘：「尿素樹脂（高分子文庫 19)」, 高分子 化学刊行会 (昭和 35 年)

6）たとえば, 鶴田四郎, 飯島貞善：工化，58，534 (1955)

7) 中島三喜男：高化, 21，529(1964)

8) 中島三喜男：高化, 21, 538(1964)

9）小枝幾久雄：工化，60，1567(1957)

10）たとえば，鶴田四郎，小鹿野うた：工化，58，474 (1955)

11）たとえば, 井本 稔, 垣内 弘：高化, 5, 117 (1948)

\footnotetext{
*・成形圧は、硬化に対して影餐は少ない(第 1 報)。

*3適正硬化度におけるホルムアルデヒド溶出量については,
} 別に報告する。 


\title{
Studies on Hardening of Amino Resins
}

III. Relations between the Degree of Cure of Melamine-Formaldehyde Resin and the Curing Conditions, and Kinetics of Condensation at C-Stage

\author{
By Mikio Nakajima*
}

The relations between the degree of cure (the value obtained by "formaldehyde isolation test") and the curing conditions were studied on melamine-formaldehyde resin laminates.

The rate equation for hardening of resin in $\mathrm{C}$-stage was proposed and the apparent activation energy was ca. $20.5 \mathrm{kcal} / \mathrm{mol}$.

Further, the effect of catalyst on curing temperature and time was studied quantitatively. Main experimental equations were shown below.

$$
\begin{aligned}
& F(t \cdot T a) k_{1}=k_{2} \\
& \text { ( } C=\text { const.) } \\
& F\left(T_{c} \cdot C^{a^{\prime}}\right) k_{1}{ }^{\prime}=k_{2}{ }^{\prime} \quad\left(t_{c}=\text { const. }\right) \\
& F\left(C \cdot t_{c} a^{\prime \prime}\right) k_{1}^{\prime \prime}=k_{2}^{\prime \prime} \quad\left(T_{c}=\text { const. }\right) \\
& F\left\{t_{c}\left(T_{c} \cdot C^{\alpha}\right)^{\beta}\right\} r=\delta \\
& -\left(\frac{\partial F}{\partial t}\right)_{T}=K F^{n} \quad\left(n=\frac{k_{1}+1}{k_{1}}, \quad K=k_{1} \cdot k_{2}{ }^{-1} k_{1} \cdot T a\right)
\end{aligned}
$$

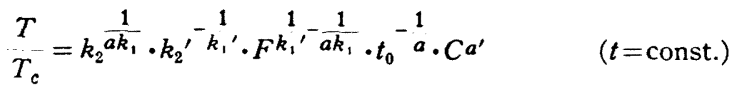

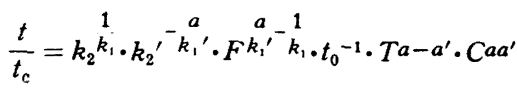

The notations are

$F:$ degree of cure $\left(\mathrm{mg} / 100 \mathrm{~cm}^{2}\right)$

$T,\left(T_{c}\right)$ : curing temperature $\left({ }^{\circ} \mathrm{K}\right)$, (when using catalyst)

$t,\left(t_{c}\right)$ : curing time (min), (when using catalyst)

$C$ : catalyst added in varnish (\%)

$a, a^{\prime}, a^{\prime \prime}, k_{1}, k_{1}{ }^{\prime}, k_{1}{ }^{\prime \prime}, k_{2}, k_{2}{ }^{\prime}, k_{2}{ }^{\prime \prime}$,

$\alpha, \beta, \gamma, \delta, t_{0}:$ const.

* Nippon Carbide Industries Co., Inc., Tokyo Research Laboratory (615 Kamiikegami-machi, Ōta-ku, Tokyo) 